\title{
Performance Evaluation of IFAS System Using Honeycomb PVC Media
}

\author{
Sara A. Rashed Mona M. Galal Khaled Zaher* \\ Public Works Dept., Faculty of Engineering, Cairo University, 12613 Giza, Egypt
}

\begin{abstract}
Recently, Egypt is facing serious problems caused by the deterioration of effluent quality of many wastewater treatment plants (WWTP) especially in rural areas. Unexpected rapid increase in population associated with the increase of organic loading are the main factors causing the failure in operation for many WWTPs. Absence of periodic maintenance and lack of operators' experience in these rural areas make the situation worse. Many WWTP are recently under rehabilitation and upgrading for the above reasons, however decision makers are facing a real challenge due to the space-limit in many cases. The integrated fixed film activated sludge (IFAS) system has recently proved to be an effective choice to expand the WWTP capacity for growing communities, enhance nitrogen removal and comply with more stringent effluent limits with small footprint. In this research, an IFAS pilot-scale reactor is constructed to optimize its application in upgrading conventional activated sludge (CAS) plants. The effect of carrier position, hydraulic retention time (HRT) and organic loading rate (OLR) on the biological treatment efficiency and nutrient removal compared to CAS process are studied. IFAS configurations with no media, vertical position and cross flow media position are tested with 4, 8 and 12 hours retention times and organic loading rates of 0.84 and $1.44 \mathrm{Kg} \mathrm{COD} / \mathrm{m}^{3}$.day.
\end{abstract}

Keywords: Integrated fixed film IFAS, biological nitrogen removal, honeycomb PVC media

DOI: $10.7176 / \mathrm{CER} / 11-2-06$

Publication date:March $31^{\text {st }} 2019$

\section{INTRODUCTION}

Wastewater treatment systems depend mainly on the biological action of different types of microorganisms, primarily bacteria, for removing dissolved and suspended organic matter (Schultz 2005; Ahmed et al. 2013). Biological treatment processes can be principally divided into aerobic and anaerobic processes where they can be further subdivided into suspended-growth processes, attached-growth processes or a combination of both (Ahmed et al. 2015; Safwat et al. 2018). In suspended growth processes, the microorganisms responsible for treatment are maintained in suspension by appropriate mixing methods as in Activated sludge process (ASP), sequencing batch reactor (SBR), stabilization ponds and extended aeration systems. Whereas in attached growth processes the microorganisms are attached to some inert medium, such as rock, slag or specially designed ceramic or plastic materials applied in Trickling Filters (TF) and Rotating Biological Contractors (RBC). Suspended growth processes provide operation flexibility and high degree of treatment quality while attached growth processes are inherently stable and resistant to organic and hydraulic shock loadings. Recently, the combination of both processes is widely applied to achieve the advantages of both processes as in Integrated Fixed-film Activated Sludge (IFAS) process (Weerapperuma et al. 2005; Safwat 2018).

The IFAS process combines a fixed-film media in a suspended growth reactor to increase the total biomass stocking for an enhanced treatment without increasing solids loading to the sequent clarifiers. The media on which the biofilm develops are carefully designed with high internal surface area having density slightly less than that of water so that it can easily buoy. There are various types of media which can be used for the microbial growth but the most commonly used solid surface for attached growth processes are stones, clinker, sand, activated charcoal, ceramic, metals, plastic sheets, and foams (Shrestha 2013; ahmed et al. 2016). (Ngo et al. 2006) used prism-shaped sponge in wastewater treatment and obtained significant increase in performance in terms of both organic and nutrient removal efficiencies. (Nazem et al. 2014) examined the benefits of using a biofilm sequencing batch reactor (BSBR) when compared to a conventional treatment methods for the dairy wastewater and proved that the performance of BSBR system, the addition of plastic suspended media of just $4 \%$ of the SBR volume saved about $34 \%$ of reactors' volume to reach the same efficiencies. (Rajput et Khambete 2010) also emphasized the superiority of Sequencing batch biofilm reactor (SBBR) over SBR due to better process performances of organic and nutrient removal.

IFAS systems have been increasingly known as an economical alternative for treatment capacity expansion in conventional activated sludge plants and also for biological nutrient removal (BNR) upgrades (Ye et al., 2009). By encouraging the growth of both carbonaceous-removing and nitrifying bacteria, an IFAS process can improve effluent quality without expanding the plant. (Lariyah et al. 2005).

In this research, an IFAS pilot-scale reactor is constructed to optimize its application in upgrading conventional activated sludge (CAS) plants. The efficiency of biological treatment and nutrient removal of two different systems i.e. CAS and the IFAS are compared in order to examine the feasibility of IFAS systems in the 
upgrading of existing CAS plants.

\section{METHODOLOGY}

\subsection{Lab-Scale Reactor}

The reactor was installed and operated at Imyay wastewater treatment plant laboratory. The laboratory biological scale system consisted of an aeration reactor, a feeding tank of 200 liters, and three small submersible pumps as shown in Fig. 1. The IFAS reactor was designed with an area of $(0.40 \mathrm{~m} \mathrm{X} 0.30 \mathrm{~m})$ and a height of $0.30 \mathrm{~m}$ and a working volume of $20 \mathrm{~L}$. The reactor was made from glass in order not to be deformed, and transparent to observe the biofilm formed on the fixed honeycomb structured PVC media in the reactor. A baffle wall was placed at the entrance of the reactor for the uniformity of the flow. A feeding pump was used for transferring the synthetic wastewater from the feeding tank to the reactor, a waste activated sludge (WAS) pump for wasting the excess activated sludge from the reactor and a return activated sludge (RAS) pump for the returned activated sludge. The activated sludge was taken from the SBR tanks of Imyay wastewater treatment plant, with SRT 11 days. An air diffuser system was used for the aeration.

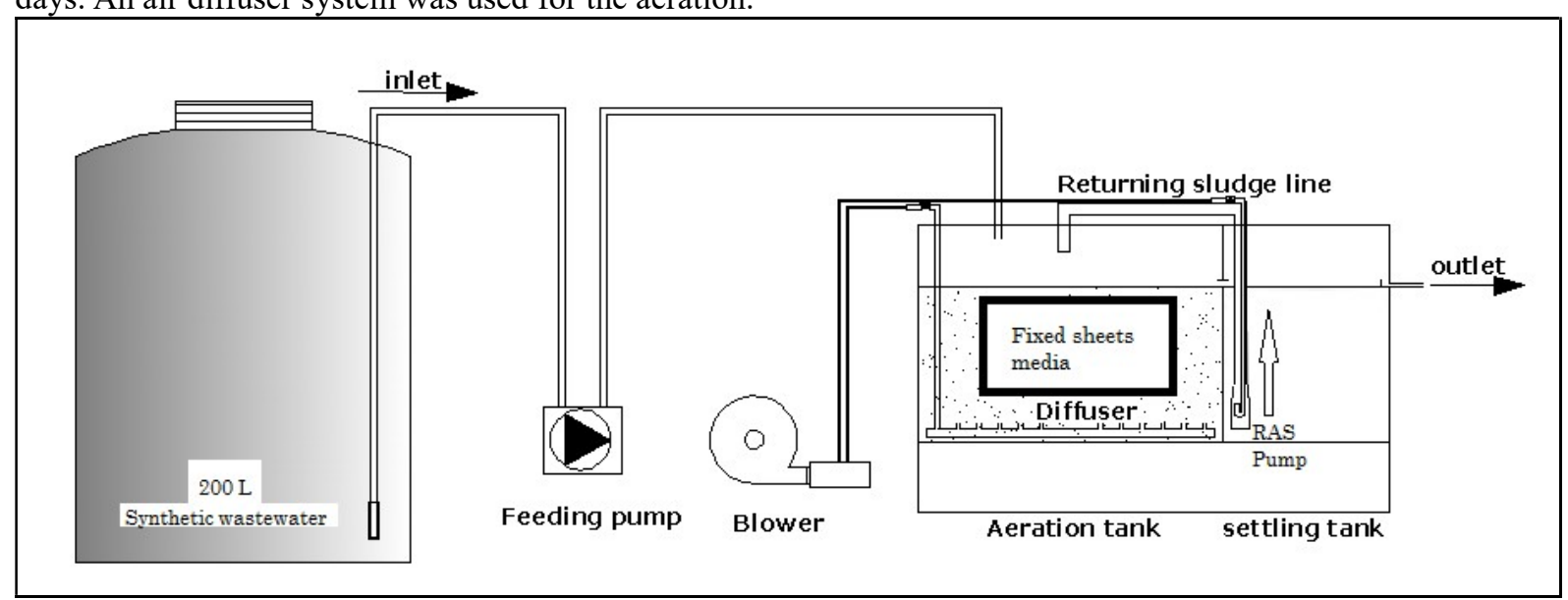

Figure 1. Schematic diagram for the lab-scale process

\subsection{Synthetic wastewater}

Synthetic wastewater was used to simulate real domestic wastewater containing biodegradable organic pollutants with a constant concentration in its characteristics that lead to a high accuracy analysis. The C: N: P ratio is 100 : 10: 1.9 which is very similar to the domestic wastewater, the composition and its concentration is shown in the Table 1. This synthetic sample gives a mean COD of $420 \mathrm{mg} / \mathrm{l}$ as shown in the Table 2.

Table 1. Synthetic wastewater compounds

\begin{tabular}{|c|c|c|}
\hline Compound & C.F & $\mathrm{mg} / \mathrm{l}$ \\
\hline Peptone & - & 25 \\
\hline Na-acetate & $\mathrm{C}_{2} \mathrm{H}_{3} \mathrm{NaO}_{2}$ & 120 \\
\hline Meat extract & - & 25 \\
\hline Glycerol & $\mathrm{C}_{3} \mathrm{H}_{8} \mathrm{O}_{3}$ & 55 \\
\hline Potato starch & - & 55 \\
\hline Milk powder & - & 120 \\
\hline Urea & $\mathrm{CH}_{4} \mathrm{~N}_{2} \mathrm{O}$ & 80 \\
\hline Ammonium chloride & $\mathrm{NH}_{4} \mathrm{Cl}$ & 25 \\
\hline Potassium dihydrogen orthophosphate & $\mathrm{KH}_{2} \mathrm{PO}_{4}$ & 35 \\
\hline Magnesium sulphate & $\mathrm{MGSO}_{4}$ & 10 \\
\hline
\end{tabular}

Table 2. Synthetic wastewater concentration

\begin{tabular}{|c|c|c|}
\hline Parameter & Value & Unit \\
\hline PH & 7.8 & - \\
\hline COD & 420 & $\mathrm{ppm}$ \\
\hline BOD5 & 280 & $\mathrm{ppm}$ \\
\hline TN & 42.4 & $\mathrm{ppm}$ \\
\hline TP & 7.85 & $\mathrm{ppm}$ \\
\hline
\end{tabular}

\subsection{Fixed honeycomb structured PVC Media}

Fixed media systems based on honeycomb structured PVC media was used in the experiments as shown in Fig. 3. 
This configuration offers an excellent combination of high performance and low cost without the concern of predation problem often found in fabric media-based systems (Ye et al., 2010a). As presented in Table 3, the honeycomb structured PVC media has a large surface area of $120 \mathrm{~m}^{2} / \mathrm{m}^{3}$ with $95 \%$ voids which helps in the uniform redistribution of wastewater and air while maximizing the contact area between the biomass and the wastewater.

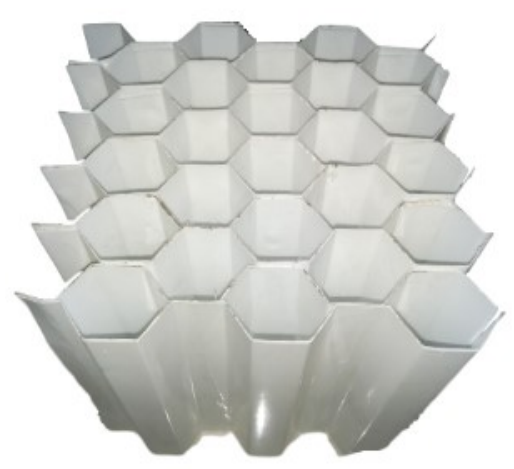

Figure 3. Honeycomb PVC Structured media

Table 3. Technical specification of the fixed media

\begin{tabular}{|c|c|c|}
\hline Effective specific surface area & 120 & $\mathrm{~m}^{2} / \mathrm{m}^{3}$ \\
\hline Media height & 21 & $\mathrm{~cm}$ \\
\hline Media length & 21 & $\mathrm{~cm}$ \\
\hline Media width & 21 & $\mathrm{~cm}$ \\
\hline Specific gravity & 1.4 & $\mathrm{~g} / \mathrm{cm}^{3}$ \\
\hline Voids & 95 & $\%$ \\
\hline Density & 1.3 & $\mathrm{~g} / \mathrm{cm}^{3}$ \\
\hline Media fill rate range & 50 & $\%$ \\
\hline
\end{tabular}

\subsection{Experimental Work}

The experiment was carried out in three phases as shown in Figs (4-6). The first phase consists of three stages: the first stage is an activated sludge process (no media), the second stage is an integrated fixed film activated sludge process with a fixed honeycomb structured PVC media added in a vertical position and in the third stage the media is added in a cross-flow position. The second phase is carried to study the change in hydraulic retention time, and the third phase to study the effect of changing the organic loading rate.

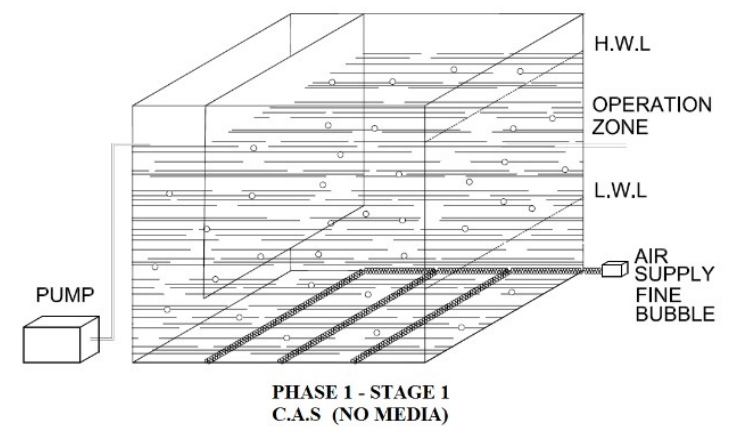

Figure 4. phase 1 - stage 1 (no media) 


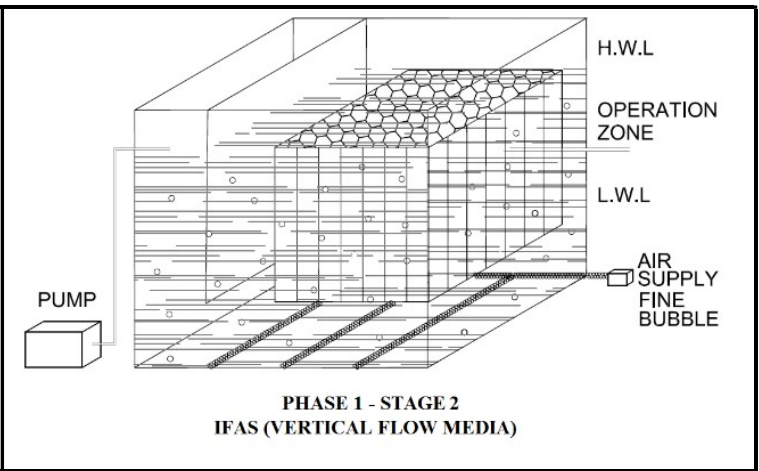

Figure 5. Phase 1 - stage 2 (vertical flow media)

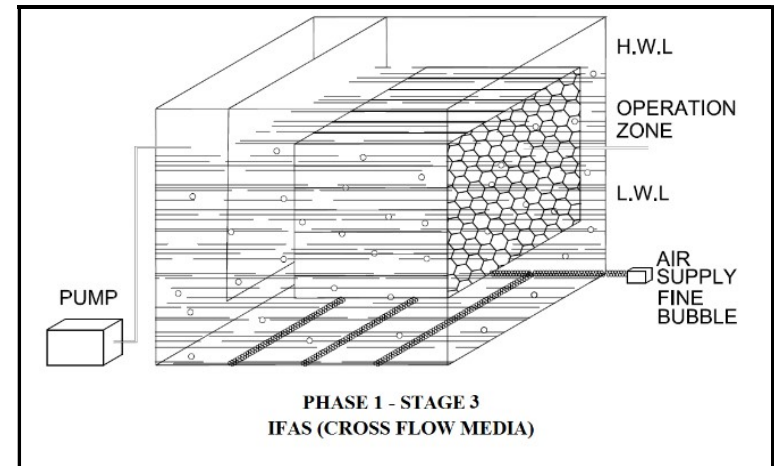

Figure 6. Phase 1 - stage 3 (cross flow media)

\section{RESULTS AND DISCUSSION}

\subsection{Effect of Media Position (Phase 1)}

This phase studied the effect of adding a fixed media and its effect on the efficiency of biological treatment and nutrient removal. The HRT was adopted to be 12 hours with a flow rate of $1.67 \mathrm{l} / \mathrm{hr}$.

This phase is divided into three stages: stage one was operated without media as a simulation of conventional activated sludge system, in stage two, a honeycomb structured PVC media was added to the reactor in a vertical flow position covering $50 \%$ of the reactor volume and as a simulation of an IFAS system and in stage three the position of media was changed to cross flow position. All samples were analyzed for $\mathrm{BOD}_{5}, \mathrm{COD}$, total nitrogen and total phosphorous removal and the results are illustrated in Figs. 7-10.

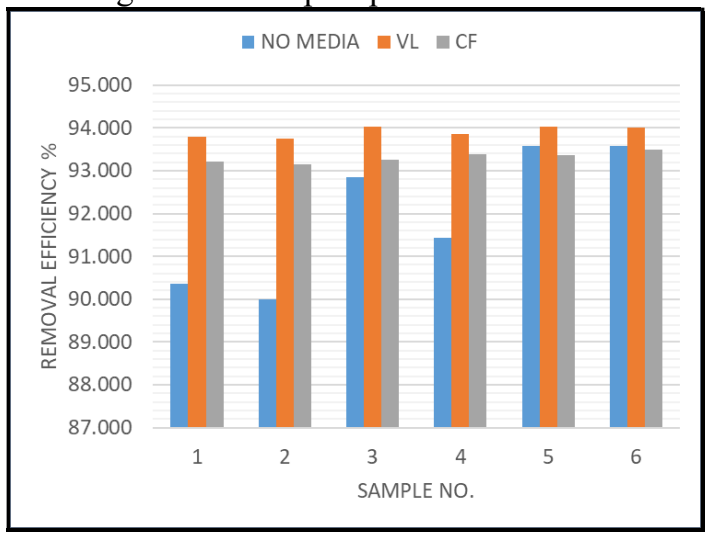

Fig. 7 BOD Removal \% at Different Media Positions

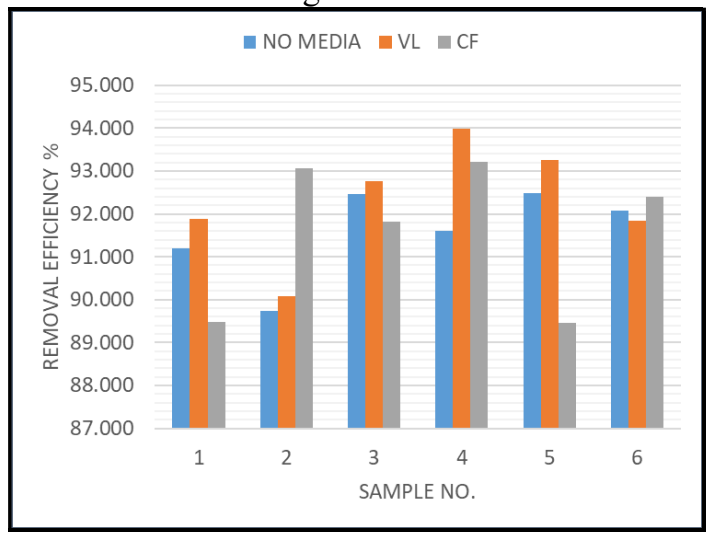

Fig. 8 COD Removal \% at Different Media Positions 


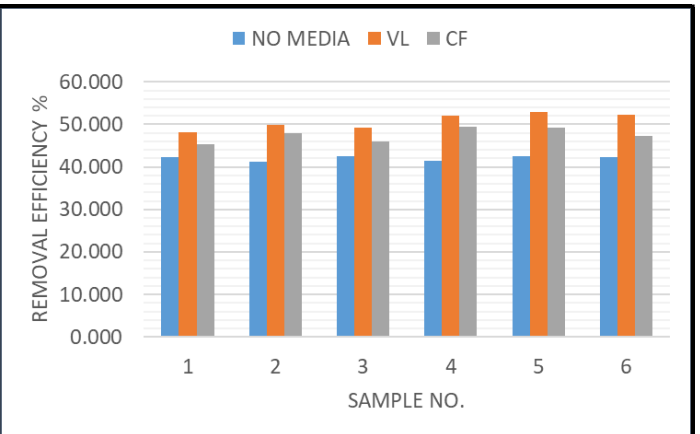

Fig.9 TN Removal \% at Different Media Positions

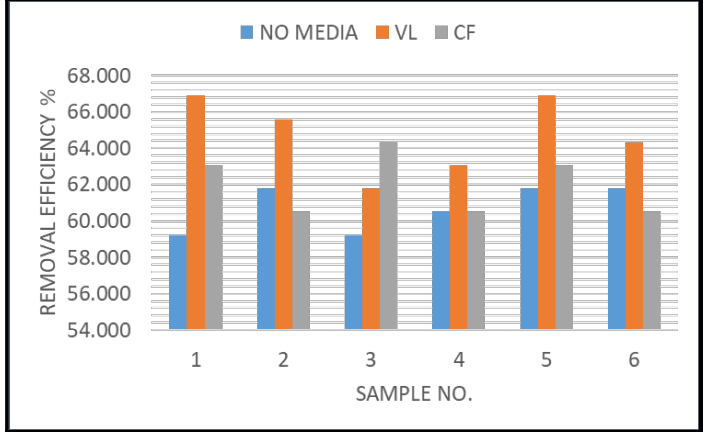

Fig. 10 TP Removal \% at Different Media Positions

The pervious results indicated that average biological and nutrient removal efficiencies were significantly affected by adding a fixed media as it offered a big surface area for the biological microorganisms to attach and grow. It was also observed that VL flow media proved to be more efficient than CF media. This may be attributed to the fact that vertical flow position offers improved wetting of media surface, larger hydraulic residence time, enhanced oxygen transfer efficiency, and has shown its optimum use for applications treating strong wastes with potentially thicker biomass growth. It also optimizes the airlift pumping through the media and provides adequate mixing and enhanced biomass control (Ye et al. 2010b). The cross-flow media is more prone to solids retention and fouling because of its more complicated media geometry and reduced flushing effects and poor oxygen transfer efficiency. TN removal was also monitored during the experiment at the different media positions. Basically, total nitrogen removed from wastewater by biological nitrification and denitrification process under aerobic and anaerobic conditions.

The following table summarize phase one removal efficiency according to media positions changes.

Table 4. Average removal rates for phase one

\begin{tabular}{|c|c|c|c|c|}
\hline Media Positions & \% BOD $_{5}$ & $\begin{array}{c}\% \\
\text { COD }\end{array}$ & $\begin{array}{c}\% \\
\text { TN }\end{array}$ & $\begin{array}{c}\% \\
\text { TP }\end{array}$ \\
\hline NO MEDIA & 91.9 & 91.5 & 42.0 & 60.7 \\
\hline VL & 93.9 & 92.2 & 50.7 & 64.7 \\
\hline CF & 93.3 & 91.5 & 47.5 & 61.9 \\
\hline
\end{tabular}

\subsection{Effect of Changing Hydraulic Retention Time (Phase 2)}

Phase two studied the effect of changing the hydraulic retention time (HRT) in the IFAS reactor and its effect on the biological treatment and nutrient removal efficiencies. This phase was divided into three stages: stage one the HRT was 12 hours then stage two it was reduced to 8 hours and finally reduced to 4 hours in stage three. The media in the reactor was kept in a vertical flow position as it previously improved to be more efficient. All the samples were analyzed for $\mathrm{BOD}_{5}, \mathrm{COD}$, total nitrogen and total phosphorous and the results are illustrated in Figs. 11-14.

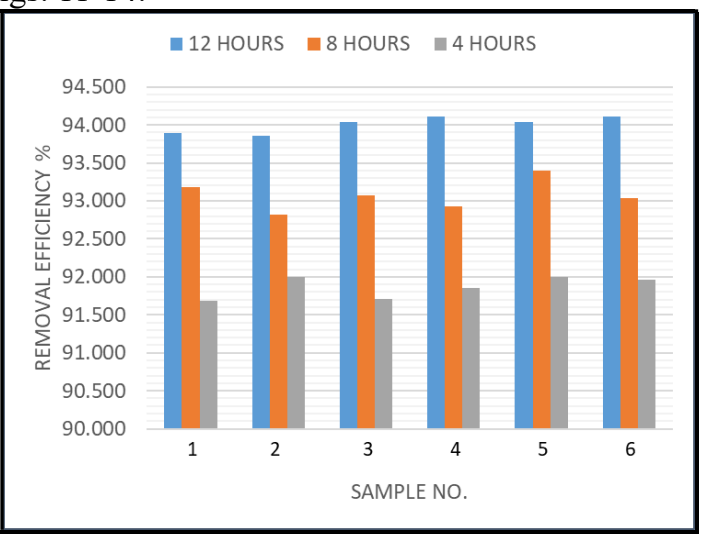

Fig. 11 BOD Removal \% at Different HRT

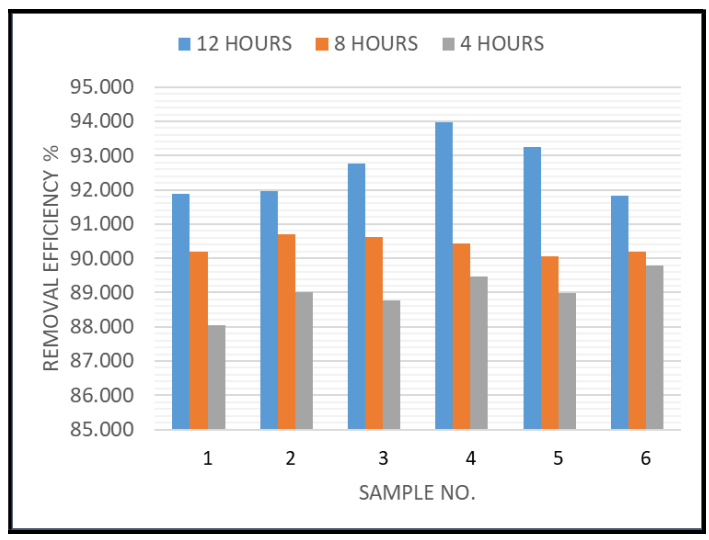

Fig. 12 COD Removal \% at Different HRT 


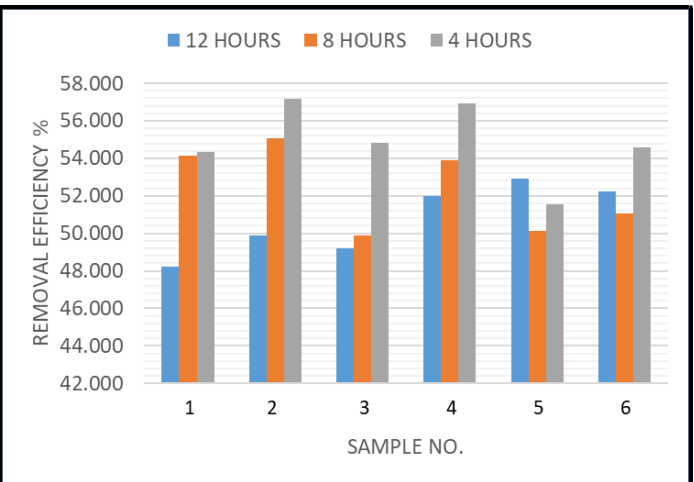

Fig. 13 TN Removal \% at Different HRT

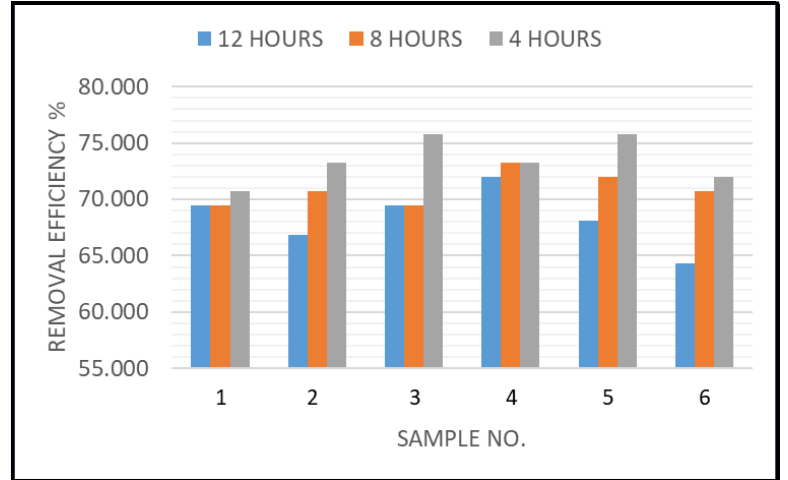

Fig. 14 TP Removal \% at Different HRT

The pervious results indicated that the average biological removal efficiencies were significantly affected by changing the hydraulic retention time. Generally, higher HRT provides enough contact time for the biodegradation of the organic matter in the reactor. A longer contact time between media and wastewater provides sufficient time for the attachment of microorganisms on the fixed film surface and developing a very active biomass layer and hence enhancing the pollutant removal efficiency (Najafpour et al. 2005)

Contrarily, nutrient removal efficiencies remarkably increased with the decrease of HRT. This may be due to that nutrient removal is enhanced with the increase of MLSS concentration. Change of HRT was attained by changing the organic loading rate while keeping the F/M ratio constant and so the MLVSS had been increased according to each HRT stage. The removal efficiencies with the change of HRT is illustrated in Table 5.

Table 5. Average removal rates for phase two

\begin{tabular}{|c|c|c|c|c|}
\hline Hydraulic Retention Time & \% BOD5 & \% COD & \% TN & \% TP \\
\hline 12 HOURS & 94.0 & 92.6 & 50.7 & 68.3 \\
\hline 8 HOURS & 93.0 & 90.3 & 52.3 & 70.9 \\
\hline 4 HOURS & 91.8 & 89.0 & 54.9 & 73.4 \\
\hline
\end{tabular}

\subsection{Effect of Changing Organic Loading Rate (Phase 3)}

In this phase the effect of changing the organic loading rate (OLR) in the IFAS reactor and its effect on the biological treatment and nutrient removal efficiencies were studied.

This phase was divided into two stages: in the first stage the COD was $420 \mathrm{mg} / \mathrm{l}$ (equivalent to OLR of 0.84 $\mathrm{Kg} \mathrm{COD} / \mathrm{m}^{3}$.day), whereas in the second stage it was increased to $720 \mathrm{mg} / \mathrm{l}$ (equivalent to OLR of $1.44 \mathrm{Kg}$ $\mathrm{COD} / \mathrm{m}^{3}$.day). The media in the reactor was kept in vertical flow position. All the samples were analyzed for $\mathrm{BOD}_{5}, \mathrm{COD}$, total nitrogen and total phosphorous and the results are illustrated in Figs. 15-18.

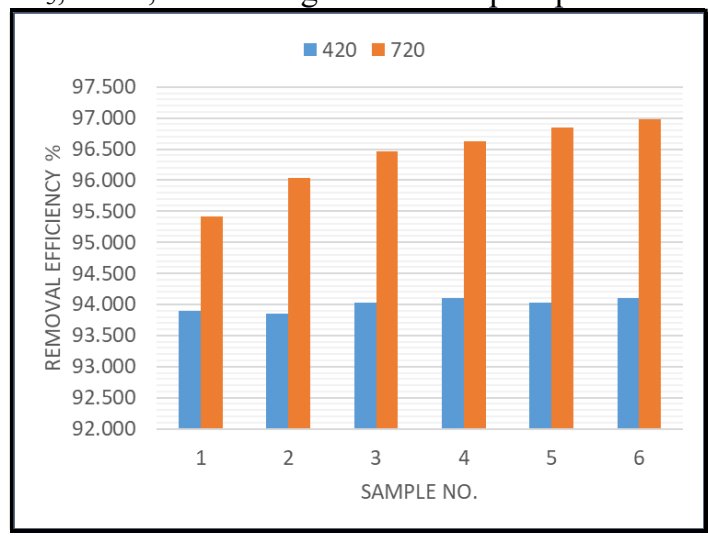

Fig. 15 BOD Removal \% at Different OLR

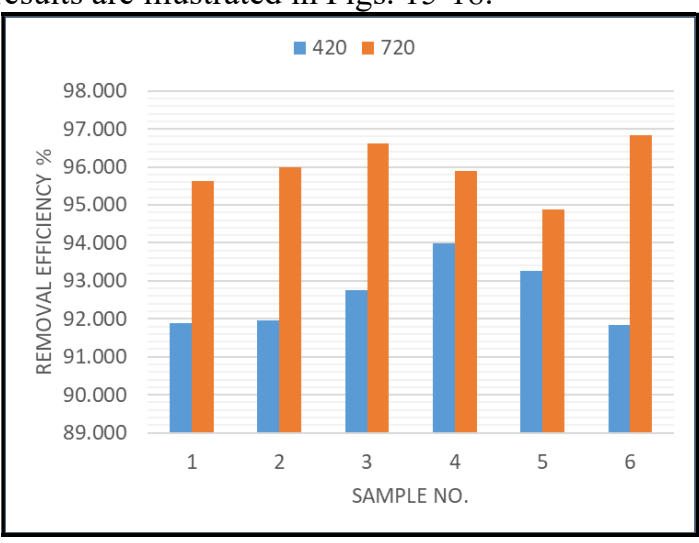

Fig. 16 COD Removal \% at Different OLR 


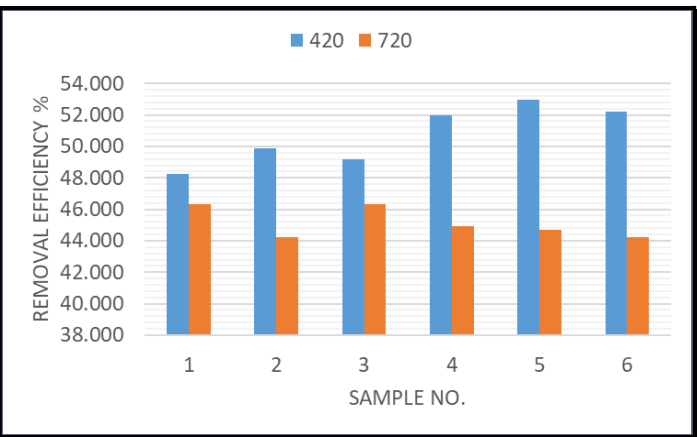

Fig. 17 TN Removal \% at Different OLR

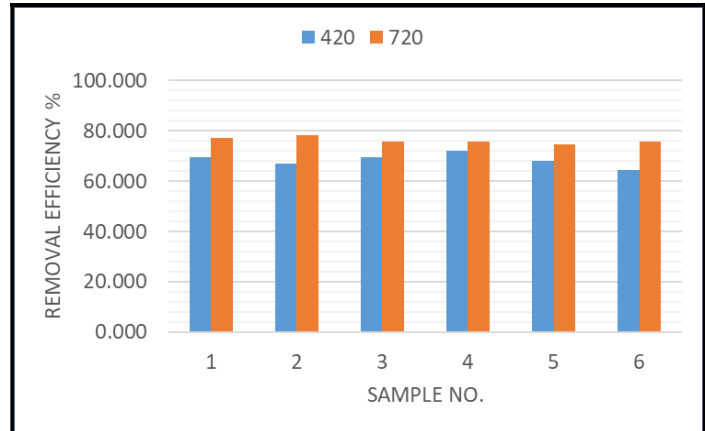

Fig. 18 TP Removal \% at Different OLR

The pervious results indicated that the average BOD and COD removal efficiencies were significantly improved by increasing the OLR. This could be explained as a result of enhancement of microbial growth and augmentation of their attachment on the fixed film when the OLR was increased. This also emphasizes the fact that IFAS system is a promising technology for the upgrading CAS systems for efficient biological organic removal.

Biological phosphorus removal is performed by phosphate accumulating micro-organisms (PAO) that have the ability to accumulate phosphate over and above what is required for growth. Due to the low influent COD at OLR of $0.84 \mathrm{~kg} \mathrm{COD} / \mathrm{m}^{3}$. d, phosphate removal efficiency was $68.3 \%$ which increased to $76.2 \%$ at OLR $1.44 \mathrm{~kg}$ $\mathrm{COD} / \mathrm{m}^{3} . \mathrm{d}$.

Nitrogen is normally removed from wastewater biologically by two consecutive processes i.e. nitrification and denitrification. Ammonia is converted to nitrite then nitrate under aerobic conditions through the nitrification process and then denitrifying bacteria change the nitrate to nitrogen gas under anoxic conditions. The outcomes of TN removal showed increase in removal efficiency rate from 45.1to $50.7 \%$ when the OLR decreased from 1.44 to $0.84 \mathrm{~kg} \mathrm{COD} / \mathrm{m}^{3}$. d. This may be due to lowering organic carbon concentrations that enhances denitrification process. (Mirhossaini et al. 2010) indicated that biological ammonia removal is highly influenced by the competition established between heterotrophic and autotrophic microorganisms. This competition depends on the COD concentration in influent wastewater. The result of his study showed that the ammonia can be removed from wastewater in high quantity in extended activated sludge if COD concentration was adjusted. Table 6 summarizes the removal efficiencies according to organic loading rates changes.

Table 6. Average removal rates for phase three

\begin{tabular}{|c|c|c|c|c|}
\hline $\begin{array}{c}\text { Organic Loading Rate } \\
\left(\mathrm{Kg} \mathrm{COD} / \mathrm{m}^{3} . \text { day }\right)\end{array}$ & $\% \mathrm{BOD}_{5}$ & $\% \mathrm{COD}$ & $\% \mathrm{TN}$ & $\% \mathrm{TP}$ \\
\hline 0.84 & 94.0 & 92.6 & 50.7 & 68.3 \\
\hline 1.44 & 96.4 & 95.9 & 45.1 & 76.2 \\
\hline
\end{tabular}

\subsection{Microbial growth and microscopic analysis}

The microbial activity was observed during all phases and it was noticed that the microbial concentration was enhanced with increasing OLR. Figure $19 \mathrm{a}$ and $\mathrm{b}$ show the microscopic image of microbial growth with OLR 1.44 and $0.84 \mathrm{~kg} \mathrm{COD} / \mathrm{m}^{3}$. d, respectively.

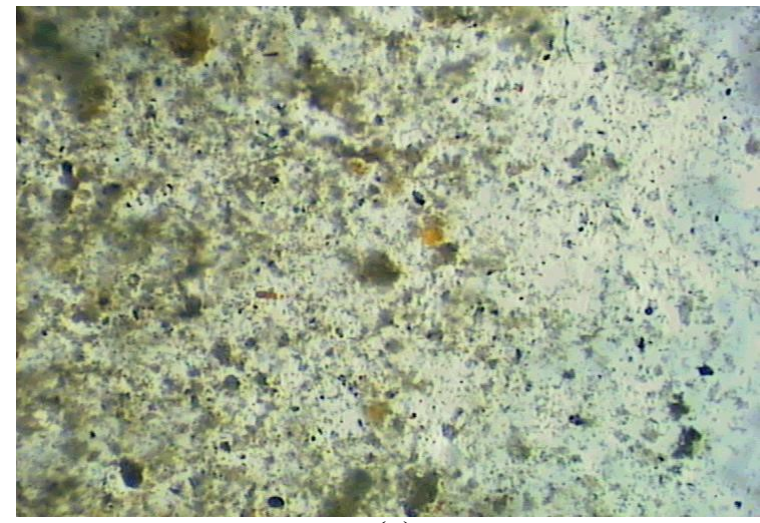

(a)

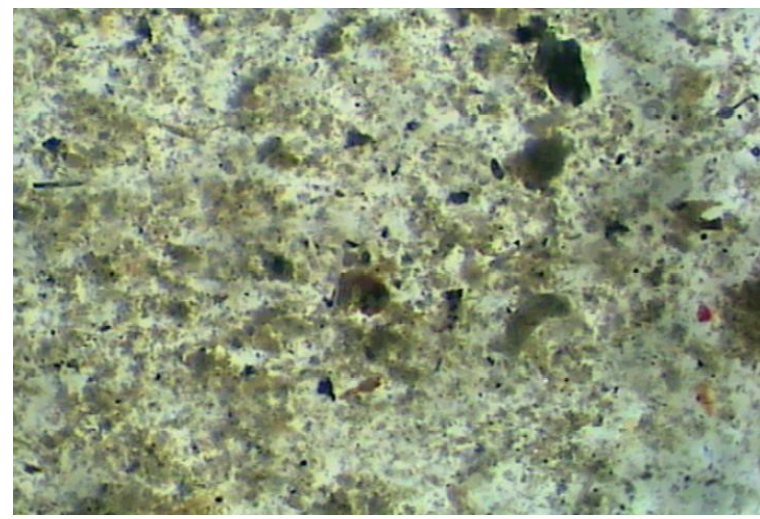

(b)

Figure 19 Microscope Image Of Mixed Liquor Biomass at OLR: a) 1.44 b) $0.84 \mathrm{kgCOD} / \mathrm{m}^{3} . \mathrm{d}$

From the previous figure it is noticed that when the reactor was operating at a $1.44 \mathrm{Kg} \mathrm{COD} / \mathrm{m} 3 . \mathrm{d}$; there was a huge presence of flocculent biomass and it was difficult to determine the shape and sizes of the biomass. 
The largest particle in this image was calculated to be of only $0.17 \mathrm{~mm}$ in equivalent diameter. Although the MLSS concentration during OLR of $1.44 \mathrm{~kg} \mathrm{COD} / \mathrm{m}^{3}$. $\mathrm{d}$ was relatively high, it consisted mostly of dispersed flocs.

While when the reactor was operating at $0.84 \mathrm{~kg} \mathrm{COD} / \mathrm{m}^{3} . \mathrm{d}$; most of the flocs were still dispersed but there was a greater number of large bio flocs. The average equivalent diameter was about $0.29 \pm 0.20 \mathrm{~mm}$. Larger bio flocs were formed with irregular and angular shapes.

\section{CONCLUSION}

Both CAS and IFAS systems had excellent removal performance for suspended solids and organic matter, however, IFAS system proved to have a good ability to receive the organic shock loads and hence can be an effective choice to expand the WWTP capacity for growing communities while complying with the more stringent effluent limits with small footprint. Adding the honeycomb structured PVC media resulted in $94 \%$, $92.2 \%, 51 \%$ and $65 \%$ removal of $\mathrm{BOD}, \mathrm{COD}, \mathrm{TN}$ and $\mathrm{TP}$, respectively. The results also emphasized that the flow position through the fixed media significantly affected the results where the vertical flow position showed higher removal efficiencies than crow flow position. Vertical flow position provided improved wetting of media surface, larger hydraulic residence time, and enhanced oxygen transfer efficiency. HRT and OLR are also very critical parameters that could enhance both organic and nutrient removal efficiencies. IFAS was capable of retaining a considerable quantity of attached biomass, which would provide successful performance and achieve appreciable organic removal. Thus, the higher the OLR led to the greater the amount of attached biomass on support material that resulted in consumption of a greater part of the substrate by this biofilm. HRT of 12 hours with OLR of $1.44 \mathrm{Kg} \mathrm{COD} / \mathrm{m}^{3} . \mathrm{d}$ resulted in $96.4 \%, 96 \%, 45.1 \%$ and $76.2 \%$ removal of BOD, COD, TN and TP, respectively. This proved that IFAS is a promising technology for the improvement of nitrification and denitrification processes and the customizing of existing CAS for biological nutrient removal.

The higher BOD, COD and T-P removal was occurred at the higher organic loading rate of $1.44 \mathrm{Kg}$ $\mathrm{COD} / \mathrm{m}^{3}$.day, otherwise the T-N removal was higher at the lowest organic loading rate of $0.84 \mathrm{Kg} \mathrm{COD} / \mathrm{m}^{3}$.day.

\section{REFERENCES}

Schultz, T. E., "Biological Wastewater Treatment", Chem. Eng., p. 52, 2005.

Ahmed, S., Abdelhalim, H., \& Rozaik, E. (2013). Treatment of primary settled wastewater using anaerobic sequencing batch reactor seeded with activated EM. Civil and Environmental Research, 3(11), 130-136.

Safwat, S. M. (2018). Performance of moving bed biofilm reactor using effective microorganisms. Journal of cleaner production, $185,723-731$.

Ahmed, S., Rozaik, E., \& Abdelhalim, H. (2015). Effect of configurations, bacterial adhesion, and anode surface area on performance of microbial fuel cells used for treatment of synthetic wastewater. Water, Air, \& Soil Pollution, 226(9), 300.

Safwat, S. M., Rozaik, E., \& Abdel-Halim, H. (2018). A comparative study on treatment of wastewaters with various biodegradability and various $\mathrm{pH}$ values using single-chamber microbial fuel cells. Water and Environment Journal.

Weerapperuma, D., De Silva, V. and Seeta, V. K., “Achieving Advanced Wastewater Treatment Standards With IFAS”, Proceedings of the Water Environment Federation, WEFTEC 2005: Session 21 through Session 30, pp. 1945-1958(14), 2005.

Shrestha, A., "Specific Moving Bed Biofilm Reactor In Nutrient Removal From Municipal Wastewater", A thesis submitted in partial fulfillment of requirements for the Degree of Master of Engineering, School of Civil and Environmental Engineering, Faculty of Engineering and Information Technology, UTS, 2013.

Ahmed, S., Rozaik, E., \& Abdel-Halim, H. (2016). Performance of single-chamber microbial fuel cells using different carbohydrate-rich wastewaters and different inocula. Polish Journal of Environmental Studies, 25(2), 503 .

Ngo, H. H., Nguyen, M. C.,Sangvikar, N. G., Hoang, T.T.L. and Guo, W. S., "Simple Approaches Towards The Design Of An Attached-Growth Sponge Bioreactor (AGSB) For Wastewater Treatment And Reuse", Water Science \& Technology, Vol. 54, pp.191-197, 2006.

Nazem, A., Elbarqi, W. and Mostafa, M., "The economical benefits of using biofilm sequencing batch reactor for dairy sequencing batch reactor for dairy", International Journal of Chemical, Environmental \& Biological Sciences (IJCEBS) Vol. 2, Issue 1, ISSN 2320-4087, 2014.

Rajput, D. C. and Khambete, A. K., "Performance of sequencing batch biofilm reactor to treat sewage", IJIRST -International Journal for Innovative Research in Science \& Technology, Vol. 1, Issue 10, 2015.

Ye, J., McDowell, C. S., Koch, K., Kulick III, F. M. and Rothermel, B. C., "Pilot Testing Of Structured Sheet Media IFAS For Wastewater Biological Nutrient Removal (BNR)", Proceedings of the Water Environment Federation, WEFTEC 2009: Session 61 through Session 70, pp. 4427-4442(16), 2009.

Lariyah, M. S., Mohiyaden, H. A., Hayder, G., Hussein, A., Basri, H., Sabri, A. F. and Noh, M. N., "System, 
Application Of Moving Bed Biofilm Reactor (MBBR) And Integrated Fixed Activated Sludge (IFAS) For Biological River Water Purification: A Short Review", IOP Conf. Ser.: Earth Environ. Sci. 32 01, 2005.

Ye. J., Kulick III, F. K. and McDowell, C. S., "Biofilm Performance of High Surface Area Density Vertical-Flow Structured Sheet Media for IFAS and Fixed Bed Biofilm Reactor (FBBR) Applications", Proceedings of the Water Environment Federation, Biofilms 2010, pp. 234-253(20), 2010a.

Ye, J., Kulick III, F. M. and McDowell, C. S., "Effective biofilm control on high surface density vertical-flow structured sheet media for submerged applications", WEFTEC, The 83rd Annual Water Environment Federation Technical Exhibition And Conference, New Orleans, LA, 2010b.

Najafpour, G., Yieng, H. A., Younesi, H. and Zinatizadeh, A., "Effect Of Organic Loading On Performance Of Rotating Biological Contactors Using Palm Oil Mill Effluents”, Process Biochemistry, Vol. 40, pp. 28792884, 2005.

Mirhossaini,S. H., Godini, H. and Jafari, A., "Effect Of Influent COD On Biological Ammonia Removal Efficiency”, International Journal of Environmental and Ecological Engineering, Vol. 4, No.2, 2010. 